\title{
Effect of Lipopolysaccharide on the Xenobiotic-Induced Expression and Activity of Hepatic Cytochrome P450 in Mice
}

\author{
Nozomu Moriya, ${ }^{a}$ Hiromi Kataoka ${ }^{b}$ Hideki Fujino, ${ }^{a}$ Jun-ichi Nishikawa,${ }^{b}$ and \\ Fumihiko Kugawa*,a \\ ${ }^{a}$ Department of Biopharmaceutics, Hyogo University of Health Sciences; 1-3-6 Minatojima, Chuo-ku, Kobe, Hyogo \\ 650-8530, Japan: and ${ }^{b}$ School of Pharmacy and Pharmaceutical Sciences, Mukogawa Women's University; 11-68 \\ Koshien Kyuban-cho, Nishinomiya, Hyogo 663-8179, Japan. \\ Received August 24, 2011; accepted January 25, 2012; published online January 31, 2012
}

Infection-associated inflammation can alter the expression levels and functions of cytochrome P450s (CYPs). $C y p$ gene expression is regulated by the activation of several nuclear receptors, including pregnane $\mathrm{X}$ receptor (PXR), constitutive androstane receptor (CAR), and aryl hydrocarbon receptor (AhR). These receptors can be activated by xenobiotics, including medicines. Here, to study the xenobiotic-induced fluctuations in CYP during inflammation, we examined the effect of lipopolysaccharide (LPS) treatment on the level of mRNAs encoding hepatic CYPs induced by xenobiotic-activated nuclear receptors, in mice. Both the mRNA induction of $C y p$ genes and the metabolic activities of CYP proteins were examined. LPS treatment caused a significant decrease in the induced expression of the mRNAs for Cyp3a11, 2c29, 2c55, and 1a2, but not for Cyp2b10. To assess the CYP enzymatic activities, CYP3A-mediated testosterone $6 \beta$-hydroxylation and the intrinsic clearance $\left(C L_{\text {int }}\right)$ of nifedipine in liver microsomes were measured in mice treated with the xenobiotic pregnenolone-16alpha-carbonitrile (PCN) with or without LPS administration. Both assays revealed that the CYP3A activity, which was induced by PCN, declined significantly after LPS treatment, and this decline correlated with the Cyp3a11 mRNA level. In addition, we found that the mRNAs for interleukin (IL)-1 $\beta$ and tumor necrosis factor (TNF) $\alpha$ were increased after treatment with LPS plus xenobiotics. Our findings demonstrated that LPS treatment reduces the PXR- and AhR-mediated, and possibly CAR-mediated Cyp gene expression and further suggest that these decreases are dependent on inflammatory cytokines in the liver.

Key words cytochrome P450; induction; lipopolysaccharide; hepatic metabolism; inflammatory cytokine; transcriptional regulation

The cytochrome P450 (CYP) enzyme superfamily is responsible for the oxidative metabolism of numerous xenobiotics, including medications. ${ }^{1)}$ CYP expression levels and enzyme activity can be altered as a result of infection-associated inflammation, and such fluctuations in CYP activity could be responsible for some unexpected failures of drug therapies and adverse side effects, including life-threatening ones. For example, during the influenza pandemic in Washington State, U.S.A., in the 1980s, severe side effects, including convulsions and cardiac conduction anomalies, occurred in children who were receiving theophylline as a prophylactic treatment for asthma. ${ }^{2)}$ This particular incident was probably owing to the decreased theophylline clearance by hepatic CYP enzymes in children infected with influenza, ${ }^{3)}$ caused by the influenza-infection-related downregulation of $C Y P$ gene expression. This incident alerted clinicians to the potential for adverse effects of an otherwise beneficial medicine in patients suffering from another disease.

Several reports have shown that the hepatic drug-metabolizing capability is reduced during infection and inflammation in human, rat, and mouse. ${ }^{4-7)}$ Morgan and colleagues reported that the mRNA levels and enzymatic activities of CYPs are downregulated in mice treated with lipopolysaccharide (LPS), ${ }^{8,9)}$ a toxic component of Gram-negative bacterial cell walls. LPS activates lymphocytes, macrophages, and neutrophils, and it initiates the synthesis of pro-inflammatory cytokines, including tumor necrosis factor (TNF) $\alpha$, interleukin (IL)-1 $\beta$, and IL- $6 .{ }^{10-12)}$ Other studies showed that the expression of these cytokines is correlated with changes in $C Y P$ gene expression and CYP enzymatic activities, during infection and inflammation. ${ }^{13-16)}$ In most of these studies, a decrease in CYP protein expression was succeeded or accompanied by a decrease in its mRNA, implicating transcription regulation as a primary mechanism. ${ }^{17)}$ These findings also underscore the importance of understanding the transcriptional mechanisms of the CYPs.

The basal and/or inducible CYP expression is affected by several factors, including gender, age, diet, hormones, and xenobiotics. ${ }^{1)}$ In particular, it is well known that the inducible expression of the Cyp gene is regulated by the binding of xenobiotics to nuclear receptors, such as the aryl hydrocarbon receptor (AhR), constitutive androstane receptor (CAR), and steroid and xenobiotic receptor (SXR) (the ortholog of the murine pregnane $\mathrm{X}$ receptor $(\mathrm{PXR}))^{18,19)}$ For example, pregnenolone-16 $\alpha$-carbonitrile (PCN), a specific agonist of mouse PXR, ${ }^{20,21)}$ binds to PXR, causing its translocation from the cytoplasm to the nucleus. PXR then heterodimerizes with retinoid $\mathrm{X}$ receptor (RXR), and the heterodimer binds to xenobiotic responsive elements (XRE) in the promoter regions of its target genes, such as Cyp3a11, to initiate their transcription. ${ }^{19,22)}$ Similarly, CAR heterodimerizes with RXR, to transcriptionally activate $C y p 2 b 10$ gene expression in response to phenobarbital and 1,4-bis-[(3,5-dichloropyridin-2-yl)oxy]benzene (TCPOBOP). ${ }^{23)}$ In addition, the expression of Cypla2 genes can be induced by AhR, which dimerizes with the AhR nuclear translocator in response to many polycyclic aromatic hydrocarbons, such as benzo $[a]$ pyrene $(\mathrm{B}(a) \mathrm{P}){ }^{24)}$

Here we used an animal model of inflammation, LPStreated mice, and focused on the xenobiotic-inducible Cyp gene expressions and CYP enzyme activities in the mouse 
Table 1. Primers for Amplification of the Listed Genes by Real-Time PCR

\begin{tabular}{lll}
\hline \hline Gene & \multicolumn{1}{c}{ Forward $\left(5^{\prime}\right.$ to $\left.3^{\prime}\right)$} & \multicolumn{1}{c}{ Reverse $\left(5^{\prime}\right.$ to $\left.3^{\prime}\right)$} \\
\hline$C y p 1 a 2$ & CAGTATCCAAGACATCACAAG & TGTGTATCGGTAGATCTCCAG \\
$C y p 2 b 10$ & ACCCCACGTTCCTCTTCCA & CAGCAGGCGCAAGAACTGA \\
$C y p 2 c 29$ & AAGGTTTTGGCGTTGTTTTTAGC & AGCTTTGGTTTTCCTCAGTTCTT \\
$C y p 2 c 55$ & CCTGAAATCTTTGGTTGATAC & GGATCTGCATGGTAACTCTG \\
$C y p 3 a 11$ & CAGCTTGGTGCTCCTCTACC & TCAAACAACCCCCATGTTTT \\
$T N F \alpha$ & GACAAGGCTGCCCCGACTACG & CTTGGGGCAGGGGCTCTTGAC \\
$I L-1 \beta$ & CAACCAACAAGTGATATTCTCCATG & GATCCACACTCTCCAGCTGCA \\
Gapdh & AACTTTGGCATTGTGGAAGG & GGATGCAGGGATGATGTTCT \\
\hline
\end{tabular}

liver. We first used this model to determine if LPS alters the PCN-inducible expression of Cyp3a11. The activity of CYP3A under the same conditions was investigated using a testosterone $6 \beta$-hydroxylation assay and the intrinsic clearance $\left(C L_{\text {int }}\right)$ of nifedipine. In addition to $C y p 3 a 11$, we evaluated the fluctuation of other Cyp mRNAs, Cyp1a2, Cyp2b10, Cyp2c29, and Cyp2c55 in the presence of their inducers, TCPOBOP or $\mathrm{B}(a) \mathrm{P}$, with and without LPS administration. Finally, we examined the levels of inflammatory cytokines during the LPSinduced fluctuation in induced CYPs.

Our results indicated that LPS downregulates the inducible expression of several Cyp genes, and that inflammatory cytokines may play a role in this process. These findings help elucidate the relationship between Cyp gene induction and inflammation.

\section{MATERIALS AND METHODS}

Chemicals LPS (0128:B12 from Escherichia coli), PCN, TCPOBOP, and $\mathrm{B}(a) \mathrm{P}$ were purchased from Sigma-Aldrich (MO, U.S.A.). $\beta$-Nicotinamide-adenine dinucleotide phosphate $\left(\mathrm{NADP}^{+}\right)$, glucose 6-phosphate, and glucose 6-phosphate dehydrogenase were purchased from Oriental Yeast (Tokyo, Japan). Testosterone, $6 \beta$-hydroxytestosterone, and nifedipine were purchased from Wako (Osaka, Japan). Other chemicals used were of super-fine or HPLC grade.

Animals Eight-week-old male Balb/c mice weighing about $22 \mathrm{~g}$ were purchased from SLC (Shizuoka, Japan). Mice were fed standard rodent chow and given water ad libitum. All animals were treated in accordance with the Guiding Principles of the "Care and Use of Laboratory Animals Code," approved by Mukogawa Women's University.

Administration of LPS and CYP Inducers To investigate the effects of LPS on PCN-inducible Cyp3all mRNA expression and the enzymatic activity of the protein, we used $1 \mathrm{mg} / \mathrm{kg}$ LPS dissolved in saline to induce inflammation. ${ }^{18)}$ LPS was administered by intraperitoneal (i.p.) injection for 2 days, and the control mice received saline. On the first day, the mice were treated with PCN $(50 \mathrm{mg} / \mathrm{kg}$, dissolved in corn oil, i.p.), a known inducer of Cyp3a11 mRNA via the activation of PXR, ${ }^{25} 3 \mathrm{~h}$ after LPS treatment. Control mice received corn oil alone. For the experiments on Cyp2b10, Cyp2c29, and Cyp2c55 expression, TCPOBOP ( $3 \mathrm{mg} / \mathrm{kg}$, in corn oil, i.p.) was used as a CAR activator, ${ }^{23,26)}$ and for AhR-controlled Cypla2 gene expression, $\mathrm{B}(a) \mathrm{P}(100 \mathrm{mg} / \mathrm{kg}$, in olive oil, i.p.) was used. $^{25,27)}$ On the second day, the mice were sacrificed $3 \mathrm{~h}$ after the LPS treatment, and the liver was excised and used for total RNA isolation and microsomal preparation.
Isolation of Total RNA and Reverse Transcription (RT) Total RNA was isolated from mouse liver using Sepasol RNA I Super (Nacalai Tesque, Kyoto, Japan) according to the manufacturer's protocol. The RNA concentration was determined spectrophotometrically by measuring the absorbance at $260 \mathrm{~nm}$, and adjusted to $77 \mu \mathrm{g} / \mathrm{mL}$. The total RNA was stored at $-80^{\circ} \mathrm{C}$. cDNA was synthesized from total RNA using the PrimeScript RT reagent Kit (TaKaRa Bio, Shiga, Japan) according to the manufacturer's protocol. Briefly, $1 \mu \mathrm{g}$ of total RNA from each sample was resuspended in $20 \mu \mathrm{L}$ of reaction buffer with PrimeScript RT enzyme, and the mixture was incubated for $15 \mathrm{~min}$ at $37^{\circ} \mathrm{C}$. Reverse transcription was stopped by denaturing the enzyme at $85^{\circ} \mathrm{C}$.

Real-Time Polymerase Chain Reaction (PCR) The mRNA expression of the genes of interest was measured by real-time PCR using an ABI PRISM 7000 (Applied Biosystems, CA, U.S.A.). Real-time PCR was conducted using $10 \mu \mathrm{M}$ (forward and reverse) gene-specific primers (listed in Table 1) and SYBR Premix Ex TaqII (TaKaRa Bio), with $2 \mu \mathrm{L}$ cDNA/sample as the template. As an internal positive control, glyceraldehyde-3-phosphate dehydrogenase (Gapdh) mRNA was also amplified. The number of cycles and annealing temperature were optimized for each primer pair. For all the reactions, the initial denaturation was $30 \mathrm{~s}$ at $95^{\circ} \mathrm{C}$. The other PCR conditions were as follows: Gapdh and Cyp3a11, 40 cycles at $95^{\circ} \mathrm{C}$ for $5 \mathrm{~s}$ and $62^{\circ} \mathrm{C}$ for $32 \mathrm{~s}$; for Cypla2, 40 cycles at $95^{\circ} \mathrm{C}$ for $5 \mathrm{~s}$ and $55^{\circ} \mathrm{C}$ for $30 \mathrm{~s}$; for Cyp $2 b 10,40$ cycles at $95^{\circ} \mathrm{C}$ for $5 \mathrm{~s}$ and $60^{\circ} \mathrm{C}$ for $30 \mathrm{~s}$; for Cyp2c29, 40 cycles at $95^{\circ} \mathrm{C}$ for $5 \mathrm{~s}$ and $54^{\circ} \mathrm{C}$ for $30 \mathrm{~s}$; for $\mathrm{Cyp} 2 \mathrm{c} 55,40$ cycles at $95^{\circ} \mathrm{C}$ for $5 \mathrm{~s}$ and $56^{\circ} \mathrm{C}$ for $30 \mathrm{~s}$; for $T N F \alpha, 40$ cycles at $95^{\circ} \mathrm{C}$ for $5 \mathrm{~s}$ and $57.8^{\circ} \mathrm{C}$ for $1 \mathrm{~min}$; for $I L-1 \beta, 40$ cycles at $95^{\circ} \mathrm{C}$ for $5 \mathrm{~s}$ and $60^{\circ} \mathrm{C}$ for $1 \mathrm{~min}$. All experiments were conducted in duplicate using the same sample. The mRNA expressions of the genes of interest were calculated from a relative standard curve and normalized to that of Gapdh in the same sample. Results are expressed as the relative fold induction of the target gene mRNA compared with that of a control sample. The specificity of the PCR product was routinely monitored by checking the product melting curves (dissociation curves) for each reaction.

Preparation of Liver Microsomes All the procedures below were conducted at $4^{\circ} \mathrm{C}$. The excised liver was homogenized with a polytron homogenizer in $100 \mathrm{~mm}$ sodium phosphate buffer ( $\mathrm{pH} 7.4$ ) containing $3.3 \mathrm{~mm}$ magnesium chloride, and then centrifuged at $9000 \times \boldsymbol{g}$ for $10 \mathrm{~min}$. The supernatant was collected and centrifuged at $105000 \times \boldsymbol{g}$ for $1 \mathrm{~h}$. The microsomal pellet was resuspended in the same buffer and centrifuged again at $105000 \times \boldsymbol{g}$ for $1 \mathrm{~h}$. The resulting microsomal pellet was resuspended in the same buffer and stored at 
$-80^{\circ} \mathrm{C}$. The protein concentrations of the microsome samples were determined using the Bradford method with bovine serum albumin as the standard reference protein. ${ }^{28)}$

Assays for Microsomal CYP3A Activity in Hepatic Microsomes The metabolisms of testosterone and nifedipine were assayed as indicators of hepatic CYP3A activity, using high-performance liquid chromatography (HPLC). ${ }^{29,30)}$ Testosterone $6 \beta$-hydroxylation was assayed as follows. The reaction mixture $(0.5 \mathrm{~mL}$, containing $0.5 \mathrm{mg} / \mathrm{mL}$ microsomal protein, $1.3 \mathrm{~mm} \beta$-NADP ${ }^{+}, 3.3 \mathrm{~mm}$ glucose 6 -phosphate, $0.4 \mathrm{U} /$ $\mathrm{mL}$ glucose 6-phosphate dehydrogenase, $3.3 \mathrm{~mm}$ magnesium chloride, and $50 \mu \mathrm{m}$ testosterone in $100 \mathrm{~mm}$ sodium phosphate buffer ( $\mathrm{pH} 7.4)$ ) was incubated at $37^{\circ} \mathrm{C}$ for $15 \mathrm{~min}$, and the reaction was stopped by adding tert-butyl methyl ether. Corticosterone was added to the reaction mixture as an internal standard, and the sample was centrifuged at $2500 \times \boldsymbol{g}$ for $3 \mathrm{~min}$ at $4^{\circ} \mathrm{C}$. The organic layer was isolated, and the solvent was evaporated under a nitrogen gas stream. The residue was dissolved in $150 \mu \mathrm{L}$ of solvent $\mathrm{A}$, consisting of methanol, acetonitrile, and $\mathrm{H}_{2} \mathrm{O}(39: 60: 1, \mathrm{v} / \mathrm{v} / \mathrm{v})$, injected into the HPLC apparatus, and analyzed as previously described by Ashino et $a l .{ }^{30)}$ The HPLC system consisted of a model L-2130 liquid chromatograph pump, a model L-2455 diode array detector, a model L-2200 auto sampler, a model L-column oven (all from Hitachi High Technologies Co., Tokyo, Japan), and a $4.6 \times 150 \mathrm{~mm}$ COSMOSIL $5 \mathrm{C}_{18}$-MS-II packed column (Nacalai Tesque). The mobile phase consisted of solvent $\mathrm{A}$ and methanol, acetonitrile, and $\mathrm{H}_{2} \mathrm{O}(80: 18: 2$, v/v/v; solvent B). A linear gradient from $70 \%$ solvent $\mathrm{A}$ to $30 \%$ solvent $\mathrm{B}$ was run for $30 \mathrm{~min}$ at $1 \mathrm{~mL} / \mathrm{min}$. The eluate was monitored at $254 \mathrm{~nm}$.

The metabolism of nifedipine, at an initial concentration of $10 \mu \mathrm{M}$, was evaluated by the same method, except for the internal standard (testosterone) and the incubation time (10 min). The concentrations of $6 \beta$-hydroxytestosterone and nifedipine were quantified by comparison with standard curves, using the peak area ratio method. To determine $C L_{\text {int }}$ in vitro, the slope $(-k)$ of the linear regression of the $\log$ concentration versus incubation time was used as follows:

$$
C L_{\text {int }}=k \times \frac{\text { milliliters incubation mixture }}{\text { milligrams microsomes }}
$$

The velocity of the testosterone conversion to $6 \beta$-hydroxytestosterone was measured under the initial rate conditions and expressed as $\mathrm{nmol} / \mathrm{min} / \mathrm{mg}$ protein.

Statistical Analysis All results are presented as the mean \pm S.E. The results from the various experimental groups and their corresponding controls were compared using oneway analysis of variance followed by the Tukey-Kramer post $h o c$ test. The differences were considered significant when $p<0.05$.

\section{RESULTS}

Effects of LPS on the Expression of Cyp mRNAs after Treatment with Several CYP Inducers To investigate whether LPS affects the transcription of Cyp genes induced by ligands for individual nuclear receptors, i.e., PCN, TCPOBOP, and $\mathrm{B}(a) \mathrm{P}$, we conducted real-time PCR experiments. Figure 1 shows the effect of LPS treatment on the PCN-induced Cyp3a11 mRNA expression. PCN treatment alone enhanced Cyp3al1 mRNA expression in mouse liver 6-fold (gray bar).

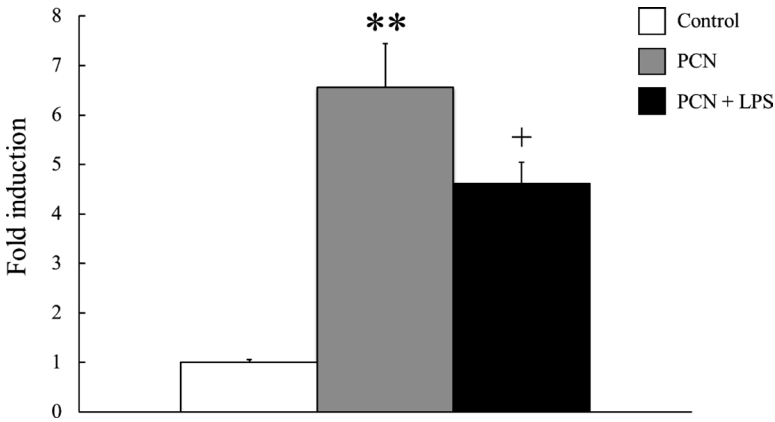

Fig. 1. Effect of LPS on the Expression of Cyp3all mRNA in PCNTreated Mice

Mice were injected with saline or LPS $(1 \mathrm{mg} / \mathrm{kg}$, i.p.) once per day, on 2 consecutive days. Three hours after the first LPS administration, the mice were treated with corn oil or PCN $(50 \mathrm{mg} / \mathrm{kg}$, i.p.). The livers were excised and total RNA was extracted $3 \mathrm{~h}$ after the second LPS administration. The Cyp3all mRNA levels were determined by real-time PCR and normalized to the Gapdh mRNA level in the same sample. Values represent the mean \pm S.E. for each group $(n=8-9)$ relative to the control group. ${ }^{* *} p<0.01$, compared with the control group. ${ }^{+} p<0.05$, compared with the PCN group.

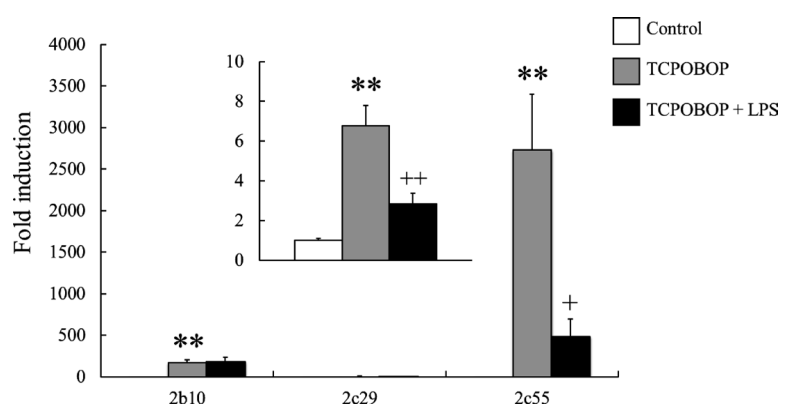

Fig. 2. Effect of LPS on the Expression of Cyp2b10, 2c29, and 2c55 mRNA in TCPOBOP-Treated Mice

Mice were injected with saline or LPS $(1 \mathrm{mg} / \mathrm{kg}$, i.p.) once per day, on 2 consecutive days. Three hours after the first LPS administration, the mice were treated with corn oil or TCPOBOP $(3 \mathrm{mg} / \mathrm{kg}$, i.p.). The livers were excised and total RNA was extracted $3 \mathrm{~h}$ after the second LPS administration. Cyp2b10, 2c29, and $2 c 55$ mRNA levels were determined using real-time PCR and normalized to the Gapdh mRNA level in the same sample. Values represent the means \pm S.E. for each group $(n=3-7)$ relative to the control group. $* * p<0.01$, compared with the control group. ${ }^{+} p<0.05,{ }^{++} p<0.01$, compared with the TCPOBOP group, Tukey-Kramer's analysis. Note that the dimension of the vertical axis for $C y p 2 c 29$ is different from that for Cyp2b10 and $2 c 55$.

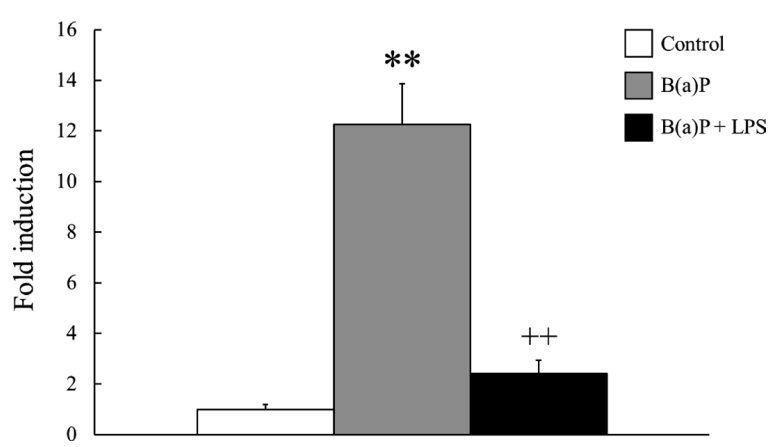

Fig. 3. Effect of LPS on the Expression of Cypla2 mRNA in $\mathrm{B}(a)$ P-Treated Mice

Mice were injected with saline or LPS $(1 \mathrm{mg} / \mathrm{kg}$, i.p.) once per day, on 2 consecutive days. Three hours after the first LPS administration, the mice were treated with olive oil or $\mathrm{B}(a) \mathrm{P}(100 \mathrm{mg} / \mathrm{kg}$, i.p.). The livers were excised and total RNA was extracted $3 \mathrm{~h}$ after the second LPS administration. The Cypla2 mRNA levels were determined using real-time PCR and normalized to the Gapdh mRNA level in the same sample. Values represent the means \pm S.E. for each group $(n=3-7)$ relative to the control group. ${ }^{* *} p<0.01$ compared with the control group, ${ }^{++} p<0.01$ compared with the $\mathrm{B}(a) \mathrm{P}$ group, Tukey-Kramer's analysis. 
Table 2. Effects of LPS on Hepatic Metabolism in PCN-Treated Mice

\begin{tabular}{|c|c|c|c|c|}
\hline Substrate & & Control & $\mathrm{PCN}$ & PCN+LPS \\
\hline Testosterone & $\begin{array}{c}6 \beta \text {-Hydroxylase }(\mathrm{nmol} / \mathrm{min} / \mathrm{mg} \\
\text { protein) }\end{array}$ & $0.85 \pm 0.09$ & $2.55 \pm 0.21 * *$ & $1.57 \pm 0.26^{+}$ \\
\hline Nifedipine & $C L_{\text {int }}(\mu \mathrm{L} / \mathrm{min} / \mathrm{mg}$ protein $)$ & $91.9 \pm 15.2$ & $481.8 \pm 36.8^{* *}$ & $345.8 \pm 21.8^{+}$ \\
\hline
\end{tabular}

Mice were injected with saline or LPS ( $1 \mathrm{mg} / \mathrm{kg}$, i.p.) once per day, for $2 \mathrm{~d}$. Three hours after the first LPS administration, the mice were treated with corn oil or PCN (50 mg/ $\mathrm{kg}$, i.p.). The livers were excised $3 \mathrm{~h}$ after the second LPS injection, and microsomes were prepared. Testosterone $6 \beta$-hydroxylase activity and the $C L_{\text {int }}$ of nifedipine were measured as described in Experimental Procedures. Data are expressed as means \pm S.E. for each group $(n=8-9)$. ${ }^{* *} p<0.01$ as compared with the control group, ${ }^{+} p<0.05$ as compared with the PCN group.

However, the administration of LPS to PCN-treated mice decreased the PCN-induced expression of Cyp3a11 mRNA by about $25 \%$ (black bar).

Similar experiments were conducted to examine the expression of Cyp2b10, Cyp2c29, and Cyp2c55 (Fig. 2). These three genes are upregulated by CAR, and TCPOBOP is one of CAR's specific ligands. As expected, TCPOBOP treatment increased the mRNA expression of Cyp2b10 (160-fold), Cyp $2 c 29$ (6-fold), and Cyp2c55 (2700-fold). However, treatment with LPS reduced the TCPOBOP-induced Cyp2c29 mRNA level by $55 \%$ and that of Cyp $2 c 55$ by $80 \%$. Interestingly, LPS treatment did not downregulate the TCPOBOP-induced level of Cyp $2 b 10$ mRNA.

Finally, we examined the expression of Cypla2 as a representative Cyp gene regulated by $\mathrm{AhR}$. Since $\mathrm{B}(a) \mathrm{P}$ is a specific ligand for $\mathrm{AhR}$, we conducted a similar experiment to those above to reveal the influence of LPS treatment on the Cypla2 gene expression. As shown in Fig. 3, $\mathrm{B}(a) \mathrm{P}$ treatment resulted in a 12-fold increase in the Cypla2 mRNA level (gray bar), which was decreased by $80 \%$ by LPS administration (black bar).

Overall, except in the case of Cyp2b10, the Cyp genes we tested showed similar responses in their induced expression when the mice were treated with LPS.

Effects of LPS on the Enzymatic Activity of CYP3A in PCN-Treated Mice Since LPS treatment attenuated the PCN-induced transcription of Cyp3a11, we examined its effects on the CYP3A activity in mouse liver microsomes. For this purpose, we assessed testosterone $6 \beta$-hydroxylase activity and the $C L_{\text {int }}$ of nifedipine, which are well-known assays of CYP3A enzyme activity. ${ }^{30)}$

Table 2 shows the effects of LPS on $6 \beta$-hydroxylase activity and the hepatic $C L_{\text {int }}$ of nifedipine under the conditions of PCN treatment alone or PCN plus LPS. The PCN-only condition induced about a 3 -fold increase in $6 \beta$-hydroxylase activity compared to controls. However, the administration of LPS with PCN significantly decreased the induced activity of this enzyme, by about $40 \%$. Similar results were obtained for nifedipine: PCN alone increased the $C L_{\text {int }}$ of nifedipine by 5.2fold, but the additional LPS treatment decreased the induction by $30 \%$.

These results suggested that the CYP3A activity was correlated with the level of Cyp3a11 mRNA expression under these experimental conditions. Fig. 4 shows the correlation profiles for the CYP3A activity and Cyp3a11 mRNA levels. Relatively good correlations were observed $\left(R^{2}=0.732\right.$ for testosterone $6 \beta$-hydroxylase activity and $R^{2}=0.659$ for the $C L_{\text {int }}$ of nifedipine).

Effects of LPS on the Expression of Hepatic Cytokines LPS is an inflammation-inducing compound that works by inducing endotoxic shock and stimulating immune cells to
(A)

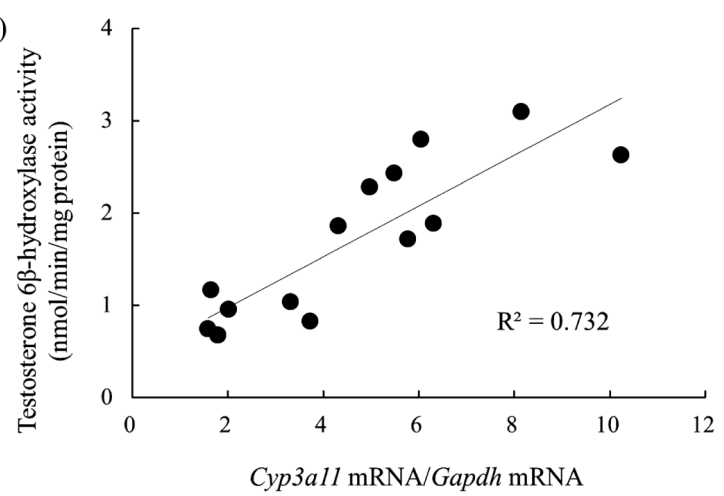

(B)

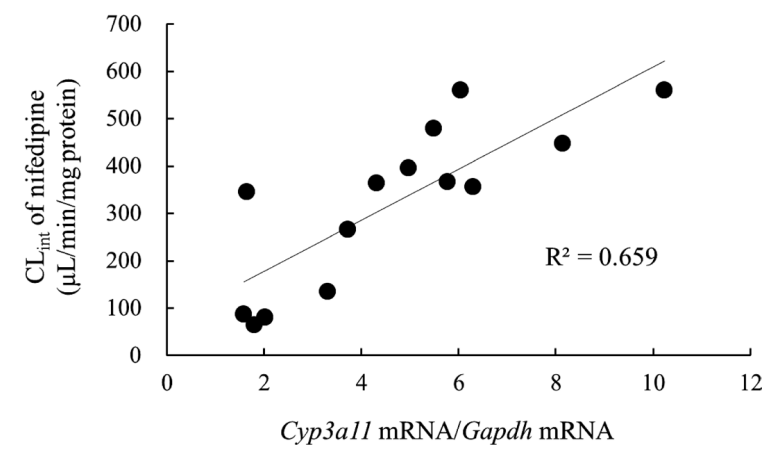

Fig. 4. Correlation between the CYP3A Activity and mRNA Level in Mouse Liver

Correlation between (A) the $C L_{\text {int }}$ of nifedipine or (B) testosterone $6 \beta$ hydroxylase activity and the Cyp3all mRNA level in the liver of control, PCN, and PCN+LPS groups $(n=4-5)$.

release inflammatory cytokines (e.g., TNF $\alpha$ and IL-1 $\beta$ ) into the blood circulation. ${ }^{12}$ These cytokines are involved in the downregulation of hepatic Cyp mRNAs. ${ }^{3)}$ To help clarify the mechanism of the LPS-induced effects on Cyp gene expression, we assessed the expression of $T N F \alpha$ and $I L-1 \beta$ mRNAs in the experimental situations described above.

We used a real-time PCR technique to determine the expression levels of $T N F \alpha$ and $I L-1 \beta$ mRNAs after mice were treated with PCN, TCPOBOP, or B(a)P, alone and with LPS (Fig. 5). As shown in Fig. 5, treatment with the individual inducers alone had no effect on the $T N F \alpha$ or $I L-1 \beta$ mRNA expression. In contrast, LPS treatment with PCN significantly increased the $T N F \alpha$ and $I L-1 \beta$ mRNA expressions, 10 -fold compared with their respective controls (Fig. 5A). We observed a similar phenomenon with TCPOBOP treatment (Fig. 5B), except that the LPS administration increased the expression of $T N F \alpha$ mRNA 4.5 -fold, and that of $I L-1 \beta$ 4-fold. $\mathrm{B}(\mathrm{a}) \mathrm{P}$ treatment elicited very similar results; LPS increased the expression of $T N F \alpha$ mRNA 5-fold and that of $I L-1 \beta$-fold (Fig. 5C). 

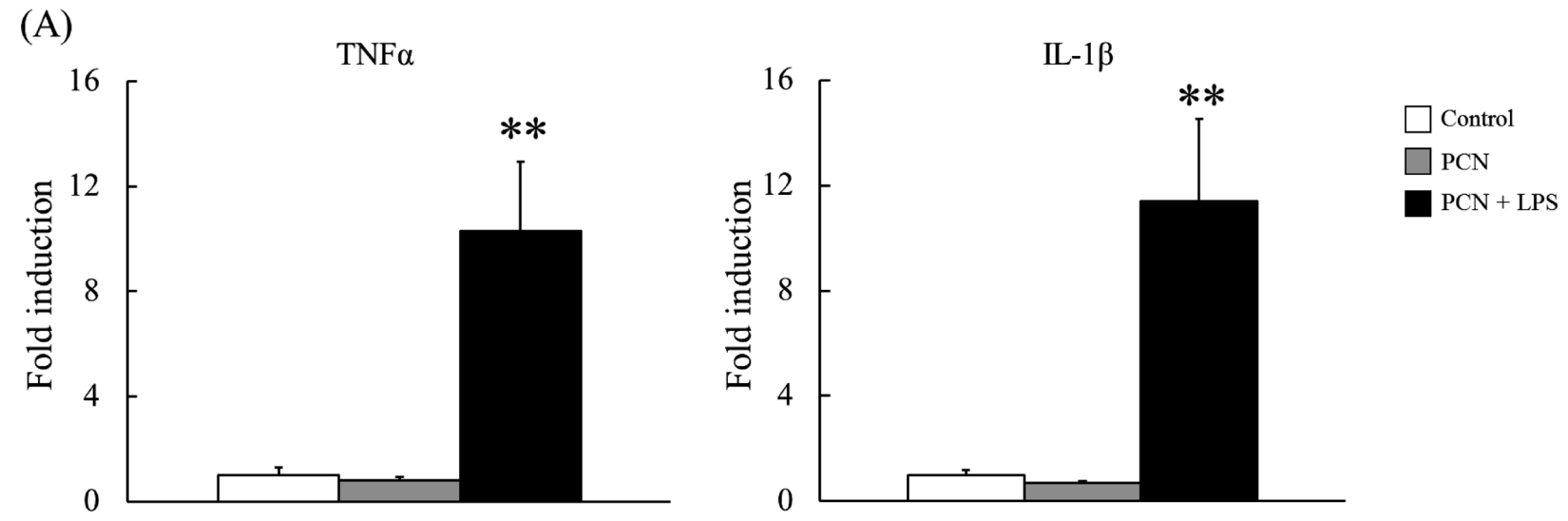

(B)
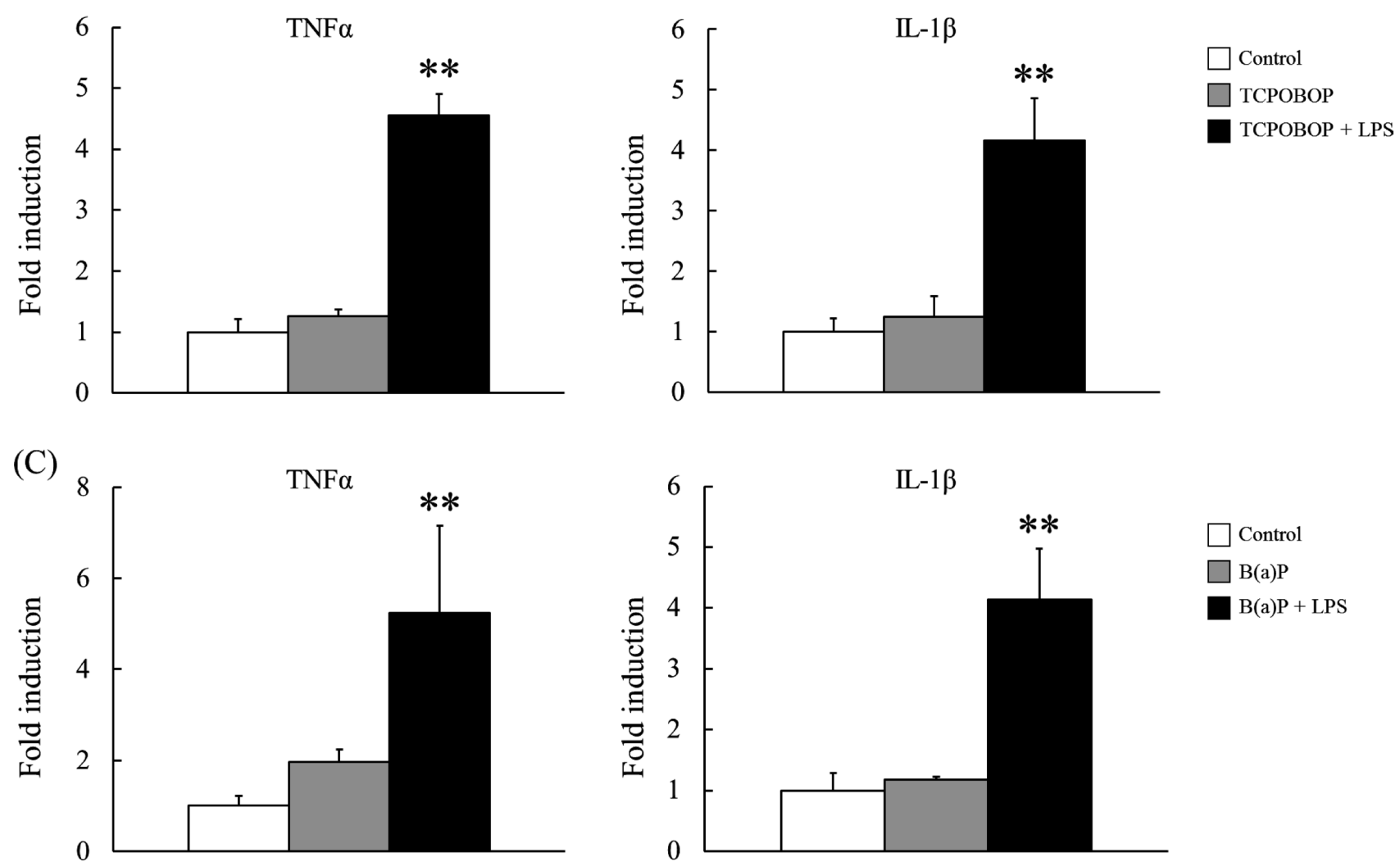

Fig. 5. Effects of LPS on the Expression of $T N F \alpha$ and $I L-1 \beta$ mRNAs in Mice Treated with $C y p$ Inducers

Mice were injected with saline or LPS ( $1 \mathrm{mg} / \mathrm{kg}$, i.p.) once per day on 2 consecutive days. Three hours after the first LPS administration, the mice were treated with (A) PCN $(50 \mathrm{mg} / \mathrm{kg}$, i. ., $n=8-9)$, (B) TCPOBOP ( $3 \mathrm{mg} / \mathrm{kg}$, i.p., $n=3-7)$, or (C) B(a)P $(100 \mathrm{mg} / \mathrm{kg}$, i. $\mathrm{p}, n=3-7)$. The livers were excised and total RNA was extracted $3 \mathrm{~h}$ after the second LPS administration. The $T N F \alpha$ and $I L-1 \beta$ mRNA levels were determined using real-time PCR and normalized to the Gapdh mRNA level in the same sample. Values represent the means \pm S.E. for each group, relative to the control group. ${ }^{* *} p<0.01$, compared with the control group, Tukey-Kramer's analysis.

These results clearly show that under the condition of the forced expression of Cyp genes, LPS treatment significantly increased the hepatic mRNA expression of the inflammatory cytokines $T N F \alpha$ and $I L-1 \beta$.

\section{DISCUSSION}

Disease states, such as bacterial infection, ${ }^{31)}$ rheumatoid arthritis, ${ }^{32)}$ and cancer, ${ }^{33)}$ lead to fluctuations in Cyp gene expressions and the enzyme activities of their products. Here we sought to examine the mechanisms underlying the fluctuations in Cyp gene expressions under an inflammatory physiological state, using LPS-treated mice as a model of inflammation.
In this study, we investigated the effects of LPS on the PCN-, TCPOBOP-, and $\mathrm{B}(a) \mathrm{P}$-induced expression of several Cyp mRNAs in mouse liver. The xenobiotics PCN, TCPOBOP, and $\mathrm{B}(a) \mathrm{P}$ are agonists for PXR, CAR, and $\mathrm{AhR}$, respectively, which are critical transcriptional regulators for inducing Cyp gene expression. Among the CYP enzymes we studied, Cyp3all was representative of PXR-regulated Cyp genes; Cyp2b10, Cyp2c29, and Cyp2c55 were representative of CAR-regulated ones; and Cypla2 was a representative AhRregulated gene. As shown in Figures 1-3, the three ligands for individual nuclear receptors induced increases of 6-2700-fold in the Cyp mRNA levels, compared to their respective control. Treatment with LPS, however, decreased the induction by 
about 25-80\%, with the exception of Cyp2b10 (Fig. 3). Thus, we found that LPS significantly downregulated the xenobioticinduced Cyp gene expressions in mouse liver, which is almost consistent with the findings of previous studies examining constitutive Cyp gene expresson. ${ }^{34)}$

To learn whether the CYP enzymes are regulated at the transcriptional or translational level, we investigated the correlation between Cyp gene expression levels and their products' enzymatic activities. To assay the activities, we measured the testosterone $6 \beta$-hydroxylation and the $C L_{\text {int }}$ of nifedipine in liver microsomes, in vitro. These two chemicals were chosen as representative medicines that are metabolized by CYP3A, which metabolizes more than $50 \%$ of the xenobiotics in the human liver. ${ }^{35)}$ As we expected, LPS significantly suppressed the PCN-induced CYP3A activity, and the CYP3A enzyme activity was correlated with the Cyp3a11 mRNA level (Fig. 4, Table 2). Similarly, Gharavi and El-Kadi reported that LPS represses the $\beta$-naphthoflavone-mediated induction of CYP1A enzyme activity. ${ }^{36}$ )

Based on experiments using cell culture systems, several mechanisms have been proposed to explain the suppression of CYP gene expression during inflammation. In particular, because many cytokines are involved in the regulation of CYP genes, and because the cytokines affect each other's expression, it is very difficult to determine which cytokine(s) regulates the expression of which CYP gene. ${ }^{17)}$ In the present study, we paid considerable attention to the inflammatory cytokines TNF $\alpha$ and IL- $1 \beta$, because they can downregulate the expression of multiple CYP genes, ${ }^{13-16)}$ suggesting that they could be key regulators of this process. Therefore, we assessed the $T N F \alpha$ and $I L-1 \beta$ mRNA levels in mice treated with LPS plus PCN, TCPOBOP, or $\mathrm{B}(a) \mathrm{P}$. In spite of the presence of CYP inducers, LPS treatment resulted in significant increases in the $T N F \alpha$ and $I L-1 \beta$ mRNAs (Fig. 5).

Among the components of cytokine-related signal-transduction pathways, nuclear factor kappa B (NF- $\kappa \mathrm{B})$, a well-known regulator of inflammation, also influences $C y p$ expression levels through its interactions with nuclear receptors. ${ }^{37)} \mathrm{Gu}$ et al. reported that $\mathrm{p} 65$, a subunit of $\mathrm{NF}-\kappa \mathrm{B}$, prevents the PXR-RXR heterodimer from binding to its consensus sequences in primary human hepatocytes. ${ }^{38)}$ Tian et al. reported that the AhR and NF- $\kappa \mathrm{B}$ signaling pathways are mutually inhibitory, in that p65 makes a complex with 2,3,7,8-tetrachlorodibenzo- $p$-dioxin (TCDD)-activated AhR, and inhibits the transcription of AhR target genes, such as Cypla2, in a murine hepatoma cell line. ${ }^{39-41)}$ These previous findings suggested that the activation of NF- $\kappa \mathrm{B}$ by LPS could trigger $C y p$ gene expression. Since we observed increased $T N F \alpha$ and $I L-1 \beta$ mRNA levels, the activation of NF- $\kappa \mathrm{B}$ by these cytokines is likely to be involved in the LPS-induced downregulation of the induced expression levels of Cyp3a11 and Cypla2 that we observed in vivo.

It is interesting that LPS treatment influenced the mRNA levels of Cyp2c29 and $2 c 55$ but not Cyp2b10 in this study, even though all these genes are known to be mainly transcriptionally regulated by CAR. Many reports have suggested that NF- $\kappa \mathrm{B}$ plays a role in the regulation of CAR. Some have concluded that exogenous LPS can also downregulate CAR target genes through the suppression of glucocorticoid receptor-mediated CAR transactivation under the control of NF- $\kappa \mathrm{B}$ during inflammation. ${ }^{42-44)}$ Thus, the LPS-induced downregulation of the Cyp2c29 and $2 c 55$ mRNA levels under
TCPOBOP treatment might occur through the activation of $\mathrm{NF}-\kappa \mathrm{B}$ in the CAR-dependent pathway. Ferrari et al. reported different regulatory mechanisms for the Cyp $2 b 1$ gene and its transcripts in rat hepatocytes exposed to LPS. ${ }^{45}$ They revealed that LPS treatment suppressed the CYP2B1 enzyme in an nitric oxide (NO)-dependent manner, although the Cyp2b1 mRNA level was transiently upregulated at the early stage of LPS treatment. So far in our experiments, we found only that LPS did not suppress Cyp2b10 gene expression after treatment with the Cyp $2 b 10$ inducer, TCPOBOP. However, the study of Ferrari et al. suggests useful ideas for our future study, aimed at understanding how Cyp2b10 gene regulation differs from that of Cyp2c29 and 2c55. As the CYP2 family enzymes are very diverse and many details of their transcriptional and translational mechanisms remain unclear, ${ }^{46}$ the above findings provide just one possible explanation for Cyp2b10's anomalous behavior. Clarifying the reason for the different behavior of Cyp2b10 is one of our primary research goals.

In conclusion, we showed that LPS-treated mice showed significantly suppressed xenobiotic-induced CYP enzyme transcription and activity, with the exception of Cyp $2 b 10$. Since CYPs are critical for the metabolism of xenobiotics, elucidating the mechanism of CYP regulation during inflammation should improve our ability to predict drug pharmacokinetics. Our current findings contribute to the understanding of how drug metabolism is altered by particular disease states, which should lead to more appropriate drug-treatment choices and dosing, as well as better patient outcomes.

Acknowledgments This work supported by KAKENHI Grant in Aid for Scientific Research (C) 22590159 to F.K. in 2010 .

\section{REFERENCES}

1) Gonzalez FJ. The molecular biology of cytochrome P450s. Pharmacol. Rev., 40, 243-288 (1988).

2) Kraemer MJ, Furukawa CT, Koup JR, Shapiro GG, Pierson WE, Bierman CW. Altered theophylline clearance during an influenza B outbreak. Pediatrics, 69, 476-480 (1982).

3) Morgan ET, Goralski KB, Piquette-Miller M, Renton KW, Robertson GR, Chaluvadi MR, Charles KA, Clarke SJ, Kacevska M, Liddle C, Richardson TA, Sharma R, Sinal CJ. Regulation of drug-metabolizing enzymes and transporters in infection, inflammation, and cancer. Drug Metab. Dispos., 36, 205-216 (2008).

4) Iber H, Sewer MB, Barclay TB, Mitchell SR, Li T, Morgan ET. Modulation of drug metabolism in infectious and inflammatory diseases. Drug Metab. Rev., 31, 29-41 (1999).

5) Aitken AE, Morgan ET. Gene-specific effects of inflammatory cytokines on cytochrome P450 2C, 2B6 and 3A4 mRNA levels in human hepatocytes. Drug Metab. Dispos., 35, 1687-1693 (2007).

6) Yang KH, Lee MG. Effects of endotoxin derived from Escherichia coli lipopolysaccharide on the pharmacokinetics of drugs. Arch. Pharm. Res., 31, 1073-1086 (2008).

7) Morgan ET. Regulation of cytochromes P450 during inflammation and infection. Drug Metab. Rev., 29, 1129-1188 (1997).

8) Li-Masters T, Morgan ET. Effects of bacterial lipopolysaccharide on phenobarbital-induced CYP2B expression in mice. Drug Metab. Dispos., 29, 252-257 (2001).

9) Sewer MB, Barclay TB, Morgan ET. Down-regulation of cytochrome P450 mRNAs and proteins in mice lacking a functional NOS2 gene. Mol. Pharmacol., 54, 273-279 (1998).

10) Koj A. Initiation of acute phase response and synthesis of cyto- 
kines. Biochim. Biophys. Acta, 1317, 84-94 (1996).

11) Gabay C, Kushner I. Acute-phase proteins and other systemic responses to inflammation. N. Engl. J. Med., 340, 448-454 (1999).

12) Ruminy $P$, Gangneux $C$, Claeyssens $S$, Scotte $M$, Daveau M, Salier JP. Gene transcription in hepatocytes during the acute phase of a systemic inflammation: from transcription factors to target genes. Inflamm. Res., 50, 383-390 (2001).

13) Li XY, Zhang C, Wang H, Ji YL, Wang SF, Zhao L, Chen X, Xu DX. Tumor necrosis factor alpha partially contributes to lipopolysaccharide-induced downregulation of CYP3A in fetal liver: its repression by a low dose LPS pretreatment. Toxicol. Lett., 179, 71-77 (2008).

14) Warren GW, Poloyac SM, Gary DS, Mattson MP, Blouin RA. Hepatic cytochrome P-450 expression in tumor necrosis factor-alpha receptor (p55/p75) knockout mice after endotoxin administration. $J$. Pharmacol. Exp. Ther., 288, 945-950 (1999).

15) Siewert E, Bort R, Kluge R, Heinrich PC, Castell J, Jover R. Hepatic cytochrome P450 down-regulation during aseptic inflammation in the mouse is interleukin 6 dependent. Hepatology, 32, 49-55 (2000).

16) Morgan ET. Regulation of cytochrome p450 by inflammatory mediators: why and how? Drug Metab. Dispos., 29, 207-212 (2001).

17) Morgan ET. Impact of infectious and inflammatory disease on cytochrome P450-mediated drug metabolism and pharmacokinetics. Clin. Pharmacol. Ther., 85, 434-438 (2009).

18) Honkakoski P, Negishi M. Regulation of cytochrome P450 (CYP) genes by nuclear receptors. Biochem. J., 347, 321-337 (2000).

19) Handschin $C$, Meyer UA. Induction of drug metabolism: the role of nuclear receptors. Pharmacol. Rev., 55, 649-673 (2003).

20) Birnbaum LS, Baird MB, Massie HR. Pregnenolone-16alphacarbonitrile-inducible cytochrome $\mathrm{P} 450$ in rat liver. Res. Commun. Chem. Pathol. Pharmacol., 15, 553-562 (1976).

21) Goodwin B, Redinbo MR, Kliewer SA. Regulation of cyp3a gene transcription by the pregnane $\mathrm{x}$ receptor. Annu. Rev. Pharmacol. Toxicol., 42, 1-23 (2002).

22) Blumberg B, Sabbagh W Jr, Juguilon H, Bolado J Jr, van Meter CM, Ong ES, Evans RM. SXR, a novel steroid and xenobioticsensing nuclear receptor. Genes Dev., 12, 3195-3205 (1998).

23) Hernandez JP, Mota LC, Huang W, Moore DD, Baldwin WS. Sexually dimorphic regulation and induction of P450s by the constitutive androstane receptor (CAR). Toxicology, 256, 53-64 (2009).

24) Shimizu $Y$, Nakatsuru $Y$, Ichinose $M$, Takahashi $Y$, Kume H, Mimura J, Fujii-Kuriyama Y, Ishikawa T. Benzo[a]pyrene carcinogenicity is lost in mice lacking the aryl hydrocarbon receptor. Proc. Natl. Acad. Sci. U.S.A., 97, 779-782 (2000).

25) Squires EJ, Sueyoshi T, Negishi M. Cytoplasmic localization of pregnane $\mathrm{X}$ receptor and ligand-dependent nuclear translocation in mouse liver. J. Biol. Chem., 279, 49307-49314 (2004).

26) Konno Y, Kamino H, Moore R, Lih F, Tomer KB, Zeldin DC, Goldstein JA, Negishi M. The nuclear receptors constitutive active/ androstane receptor and pregnane $\mathrm{x}$ receptor activate the Cyp2c55 gene in mouse liver. Drug Metab. Dispos., 38, 1177-1182 (2010).

27) Shimada $T$, Sugie A, Shindo M, Nakajima $T$, Azuma E, Hashimoto $\mathrm{M}$, Inoue K. Tissue-specific induction of cytochromes P450 1A1 and $1 \mathrm{~B} 1$ by polycyclic aromatic hydrocarbons and polychlorinated biphenyls in engineered C57BL/6J mice of arylhydrocarbon receptor gene. Toxicol. Appl. Pharmacol., 187, 1-10 (2003).

28) Bradford MM. A rapid and sensitive method for the quantitation of microgram quantities of protein utilizing the principle of proteindye binding. Anal. Biochem., 72, 248-254 (1976).

29) Konno Y, Sekimoto M, Nemoto K, Degawa M. Induction of hepatic cyp2b and cyp3a subfamily enzymes by nicardipine and nifedipine in mice. Xenobiotica, 34, 607-618 (2004).

30) Ashino T, Arima Y, Shioda S, Iwakura Y, Numazawa S, Yoshida T. Effect of interleukin-6 neutralization on CYP3A11 and metallothionein-1/2 expressions in arthritic mouse liver. Eur. J. Pharmacol.,
558, 199-207 (2007).

31) Chaluvadi MR, Kinloch RD, Nyagode BA, Richardson TA, Raynor MJ, Sherman M, Antonovic L, Strobel HW, Dillehay DL, Morgan ET. Regulation of hepatic cytochrome P450 expression in mice with intestinal or systemic infections of citrobacter rodentium. Drug Metab. Dispos., 37, 366-374 (2009).

32) Sanada H, Sekimoto M, Kamoshita A, Degawa M. Changes in expression of hepatic cytochrome P450 subfamily enzymes during development of adjuvant-induced arthritis in rats. J. Toxicol. Sci., 36, 181-190 (2011).

33) Assenat E, Gerbal-chaloin S, Maurel P, Vilarem MJ, Pascussi JM. Is nuclear factor kappa-B the missing link between inflammation, cancer and alteration in hepatic drug metabolism in patients with cancer? Eur. J. Cancer, 42, 785-792 (2006).

34) Chaluvadi MR, Nyagode BA, Kinloch RD, Morgan ET. TLR4dependent and -independent regulation of hepatic cytochrome P450 in mice with chemically induced inflammatory bowel disease. Biochem. Pharmacol., 77, 464-471 (2009).

35) Guengerich FP. Cytochrome P-450 3A4: regulation and role in drug metabolism. Аnпи. Rev. Pharmacol. Toxicol., 39, 1-17 (1999).

36) Gharavi N, El-Kadi AO. Down-regulation of aryl hydrocarbon receptor-regulated genes by tumor necrosis factor- $\alpha$ and lipopolysaccharide in murine hepatoma Hepa 1c1c7 cells. J. Pharm. Sci., 94, 493-506 (2005).

37) Xie W, Tian Y. Xenobiotic receptor meets NF-kappaB, a collision in the small bowel. Cell Metab., 4, 177-178 (2006).

38) Gu X, Ke S, Liu D, Sheng T, Thomas PE, Rabson AB, Gallo MA, Xie W, Tian Y. Role of NF-kappaB in regulation of PXR-mediated gene expression: a mechanism for the suppression of cytochrome P-450 3A4 by proinflammatory agents. J. Biol. Chem., 281, 1788217889 (2006).

39) Tian Y, Ke S, Denison MS, Rabson AB, Gallo MA. Ah receptor and NF-kappaB interactions, a potential mechanism for dioxin toxicity. J. Biol. Chem., 274, 510-515 (1999).

40) Ke S, Rabson AB, Germino JF, Gallo MA, Tian Y. Mechanism of suppression of cytochrome P-450 1A1 expression by tumor necrosis factor-alpha and lipopolysaccharide. J. Biol. Chem., 276, 3963839644 (2001).

41) Tian Y. Ah receptor and NF-kappaB interplay on the stage of epigenome. Biochem. Pharmacol., 77, 670-680 (2009).

42) Assenat E, Gerbal-Chaloin S, Larrey D, Saric J, Fabre JM, Maurel P, Vilarem MJ, Pascussi JM. Interleukin $1 \beta$ inhibits CAR-induced expression of hepatic genes involved in drug and bilirubin clearance. Hepatology, 40, 951-960 (2004).

43) Pascussi JM, Gerbal-Chaloin S, Fabre JM, Maurel P, Vilarem MJ. Dexamethasone enhances constitutive androstane receptor expression in human hepatocytes: consequences on cytochrome P450 gene regulation. Mol. Pharmacol., 58, 1441-1450 (2000).

44) Pascussi JM, Busson-Le Coniat M, Maurel P, Vilarem MJ. Transcriptional analysis of the orphan nuclear receptor constitutive androstane receptor (NR1I3) gene promoter: identification of a distal glucocorticoid response element. Mol. Endocrinol., 17, 42-55 (2003).

45) Ferrari L, Peng N, Halpert JR, Morgan ET. Role of nitric oxide in down-regulation of CYP2B1 protein, but not RNA, in primary cultures of rat hepatocytes. Mol. Pharmacol., 60, 209-216 (2001).

46) Kubota A, Stegeman JJ, Goldstone JV, Nelson DR, Kim EY, Tanabe $\mathrm{S}$, Iwata H. Cytochrome P450 CYP2 genes in the common cormorant: Evolutionary relationships with 130 diapsid CYP2 clan sequences and chemical effects on their expression. Comp. Biochem. Physiol. C Toxicol. Pharmacol., 153, 280-289 (2011).

47) Shimada $T$, Inoue $K$, Suzuki $Y$, Kawai $T$, Azuma E, Nakajima $T$, Shindo M, Kurose K, Sugie A, Yamagishi Y, Fujii-Kuriyama Y, Hashimoto M. Arylhydrocarbon receptor-dependent induction of liver and lung cytochromes P450 1A1, 1A2, and 1B1 by polycyclic aromatic hydrocarbons and polychlorinated biphenyls in genetically 
engineered C57BL/6J mice. Carcinogenesis, 23, 1199-1207 (2002).

48) Jackson JP, Ferguson SS, Moore R, Negishi M, Goldstein JA. The constitutive active/androstane receptor regulates phenytoin induction of Cyp2c29. Mol. Pharmacol., 65, 1397-1404 (2004).

49) Richardson TA, Morgan ET. Hepatic cytochrome P450 gene regulation during endotoxin-induced inflammation in nuclear receptor knockout mice. J. Pharmacol. Exp. Ther., 314, 703-709 (2005).

50) Wang H, Zhao Y, Bradbury JA, Graves JP, Foley J, Blaisdell JA, Goldstein JA, Zeldin DC. Cloning, expression, and characterization of three new mouse cytochrome p450 enzymes and partial characterization of their fatty acid oxidation activities. Mol. Pharmacol.,
65, 1148-1158 (2004).

51) Zhou C, Tabb MM, Nelson EL, Grün F, Verma S, Sadatrafiei A, Lin M, Mallick S, Forman BM, Thummel KE, Blumberg B. Mutual repression between steroid and xenobiotic receptor and NF-kappaB signaling pathways links xenobiotic metabolism and inflammation. J. Clin. Invest., 116, 2280-2289 (2006).

52) Naruyama H, Shimada M, Niida H, Zineldeen DH, Hashimoto $Y$, Kohri K, Nakanishi M. Essential role of Chk1 in S phase progression through regulation of RNR2 expression. Biochem. Biophys. Res. Commun., 374, 79-83 (2008). 